\title{
Kurumsal Yaklaşım Perspektifinden İnovasyon ve Yenilikçi Kamu Alımları
}

Doğan BAKIRTAŞ, Department of Public Finance, Faculty of Economics and Administrative Sciences, Omer Halisdemir University, Turkey; e-mail: dbakirtas@nigde.edu.tr

Ahmet AYSU, Department of Public Finance, Faculty of Economics and Administrative Sciences, Erciyes

University, Turkey; e-mail: ahmetaysu@erciyes.edu.tr

\section{Innovation and Innovative Public Procurement from the Perspective of Institutional Approach}

\begin{abstract}
Innovation policies and national innovation systems are the main determinant of countries development level. Innovative public procurement is an exceptional role among innovation policies. In this study examined innovative public procurement in the context of institutional approach. According to institutional approach countries' innovation capacities are affected by formal and informal institutions and innovative public procurement process can be understood as a set of institutions with a particular inter-relationship between governmental institutions as a buyer and private firms as a suppliers. Therefore, government should set the rules for innovative public procurement process. Government should establish the formal rules for legal infrastructure, tender methods awarded to the firms offering innovative solutions, lead to firms for adequate and more effective level of R\&D activities and increase competition in the market. On the other hand, government should give the sufficient importance to innovative solutions in public procurement process.
\end{abstract}

Keywords $\quad$ : Innovation, Institutions, Innovative Public Procurement.

JEL Classification Codes : $\mathrm{H} 57, \mathrm{O} 30, \mathrm{O} 38, \mathrm{O} 43$.

\section{Öz}

İnovasyon politikaları ve ulusal inovasyon sistemleri ülkelerin gelişmişlik düzeyini belirleyen temel faktördür. Yenilikçi kamu alımları inovasyon politikaları arasında müstesna bir role sahiptir. Bu çalışmada yenilikçi kamu alımları kurumsal yaklaşım çerçevesinde incelenmiştir. Kurumsal yaklaşıma göre ülkelerin inovasyon kapasiteleri formel ve enformel kurumlar tarafindan etkilenmekte ve kamu alım süreci; devletin satın alıcı, firmaların ise tedarikçi olarak aralarında belirli bir etkileşimin olduğu kurumlardan oluşmaktadır. Dolayısıyla devlet, yenilikçi kamu alım sürecine ilişkin kuralları düzenlemelidir. Devlet, yenilikçi kamu alım süreçlerinin hukuki altyapısını, yenilikçi çözümler sunan firmaları ödüllendiren ihale yöntemlerini, firmaların yeterli ve daha etkin düzeyde Ar-Ge faaliyetlerine yöneltecek ve piyasadaki rekabeti artıracak formel kuralları oluşturmalıdır. Diğer taraftan devlet, kamu alım süreçlerinde yenilikçi çözümlere gereken önemi vermelidir.

Anahtar Sözcükler : İnovasyon, Kurumlar, Yenilikçi Kamu Alımları. 


\section{Giriş}

İnovasyon; araştırma birimleri, iş dünyası, kamu politikaları ve siyaset üzerinde etkilere sahip olan bir konudur. Bu durum, teorik düzeyde birçok farklı iktisadi yaklaşım tarafından ele alınan bir çalışma alanı haline gelmesine neden olmuştur. Neoklasik yaklaşım çerçevesinde teknolojik gelişme, uzun dönemli ekonomik büyüme için temel faktör olarak kabul edilmektedir. $\mathrm{Bu}$ kabul nedeniyle ekonomik büyümenin ülkeler nezdinde sağlanabilmesi için teknolojiye gereken önemin verilmesi vurgulanmaktadır. İş dünyası açısından bakıldığında küreselleşme ile birlikte artan rekabet, firmaların belirli konularda diğerlerinden farklılaşması gerektiğini ortaya çıkarmaktadır. $\mathrm{Bu}$ farklılaşmanın sağlanabilmesi ve rekabet avantajlarının geliştirilebilmesi açısından inovasyon, firmalar için farklılığ1 sağlayabilecek bir faktör olarak dikkat çekmektedir (Marsh, 2010: 3-8). Bu farklılaşma gerekliliği kamu politikalarına da yansımaktadır. Son yıllarda inovasyon sürecindeki aktörleri harekete geçirmek ve bunun sonucunda ülkeler düzeyinde rekabet gücünü artırmak adına devlet sahip olduğu potansiyel nedeniyle ön plana çıkmaktadır. Bununla birlikte inovasyon süreci, toplumdaki tüm birimlerin harekete geçirilmesi ve ortak bir noktada buluşmasını sağlamak ile mümkün olabilmektedir. Bu süreçteki tüm aktörler arasındaki iletişim ve etkileşim inovasyonun başarısını farklılaştırmaktadır. Bu açıdan, toplumsal etkileşimleri gerek formel ve gerekse enformel kurumlar şeklinde tanımlayan kurumsal yaklaşım inovasyon sisteminde kilit bir rol üstlenmektedir.

İnovasyon politikaları; küreselleşme olgusu ile birlikte artan rekabetle başa çıkabilmek, devamlılığ 1 sağlayabilmek ve ülke dinamizmini ortaya çıkarabilmek gibi farklı amaçlara sahiptir. İnovasyon olgusunun tek bir kişiye, firmaya veya sektöre fayda sağlamadığı gerçeğinden hareket ederek tüm topluma yayılan faydaları olduğu göz ardı edilemez. $\mathrm{Bu}$ açıdan inovasyon politikalarının oluşturulması ve politikaların uygulanmasında devlet önemli bir kurum olarak öne çıkmaktadır. Son yıllarda birçok ülke tarafından farklı türleri kullanılan inovasyon politikalarının başında kamu alımları gelmektedir. Bunun sebebi, yüksek düzeyde satın alma gücü bulunan hükümetlerin inovasyona olan talebi artırmaya olan etkisidir. Bununla birlikte öncü kullanıcı sıfatına sahip hükümetler, inovasyon faaliyetleri açısından bir yol gösterici rolü oynamakta ve inovasyonun yayılmasını etkilemektedir (OECD, 2011: 11). Her ne kadar hükümetler parasal bir güce sahip olsa da bu durum inovasyon politikalarının mükemmel bir şekilde işlemesine ve faydalı sonuçlar doğurmasına yeterli olmayacaktır. İnovasyon sürecinde uygulanan politikaların başarısında hükümetlerin parasal gücü bir başlangıç olsa da gerek uygulamaya konulan regülasyonlar veya fikri mülkiyetin korunması gibi formel kurumların gerekse de politikaların uygulanmasında ve içselleştirilmesinde kilit role sahip toplumsal davranışları ifade eden sosyal sermaye gibi formel kurumların dikkate alınması ve harekete geçirilmesi inovasyon politikalarının başarısını artıcı birer unsurdur.

$\mathrm{Bu}$ çalışmanın amacı, inovasyon sürecinde uygulanan politikalarda başarı elde edilebilmesi için gerekli tüm iktisadi ve sosyal faktörlerin gerek formel gerekse enformel unsurlara sahip kurumsal altyapı kapsamında değerlendirilmesidir. İnovasyon sürecinin karşılıklı bir etkileşim olduğu göz önüne alındığında, devlet tarafından ortaya konulan özellikle kamu alım politikalarında başarının sağlanabilmesi için toplumda yer alan diğer 
aktörlerin davranışları da önem arz etmektedir. Söz konusu aktörlerin davranışlarını şekillendiren faktör ise kurumlardır. Bu kapsamda çalışmada öncelikle kurum ve inovasyon kavramları açıklanmış olup daha sonrasında inovasyon politikaları ve kurumlar arasındaki ilişkiye değinilmiştir. Söz konusu ilişki açıklandıktan sonra inovasyon politikalarında son yıllarda hükümetlerin önemli bir kurum olarak aktif rol oynadığı kamu alım politikaları ve kamu alımlarının etkin bir biçimde kullanılması için gerekli koşullar kurumsal yaklaşım çerçevesinde ele alınmıştır.

\section{Kurum Kavramı ve Kurumsal Yaklaşım}

Kurumların özelliklerine ve işlevlerine değinilmeden önce kurum kavramının net olarak ortaya konulması önem arz etmektedir. Ancak iktisat literatürüne bakıldığında kurum kavramı üzerinde uzlaşılmış net bir tanımlama yoktur. Kurumsal iktisat teorisyenleri tarafından ortaya atılan tanımlamalar birbirine yakın gözükse de tam anlamıyla ortak bir kurum tanımının olmadığı görülmektedir.

Kurumsal iktisadın öncü teorisyenlerinden biri olan Veblen kurum kavramını, insanların geneline yerleşmiş olan düşünce alışkanlıkları olarak tanımlamış olup kurumların örgütsel bir oluşumdan ziyade düşünce kalıpları olduğu vurgusunu yapmıştır (Sowell, 1967: 189). Veblen'e göre kurumlar alışkanlıkların doğal bir sonucudur. Kurumsal yapının gelişmesi ve değişmesi grup üyelerinin bireysel davranışlarının bir sonucu olup kurumlar bireylerin alışkanlıkları neticesinde ortaya çıkmaktadır (Veblen, 1909: 629). Commons ise kurumu, bazen bireylerin birer tutuklu gibi yasalar ve doğal haklar çerçevesinde hareket etmesi gibi görürken bazen de bir tutuklunun yapmış olduğu davranışlar şeklinde görmektedir. Genel anlamda Commons kurum kavramını, bireysel eylemin genişlemesi, serbestleşmesi ve kontrol edilmesinde kolektif eylem şeklinde tanımlamaktadır (Commons, 1931: 648). Kapp'a göre kurum kavramı hukuksal bir organizasyonu değil, geçmişten devrolan ve geleceğe kadar süren -grup alışkanlıkları ve davranış kalıplarını da içerensabitleşmiş düşünce alışkanlıkları ve davranış biçimlerini ifade etmektedir (Kapp, 1968: 2$3)$.

Yeni kurumsal iktisadın öncülerinden olan North'a göre kurumlar, toplumda oynanan oyunun kurallarıdır; daha geniş bir bakış açısıyla insanlar arasındaki etkileşimi şekillendirmek için insanlarca oluşturulmuş kısıtlamalardır. Bu kısıtlamalar, bireylerin hangi koşullar altında belli faaliyetlere girişmelerine izin verileceği veya bireylerin hangi faaliyetleri yapmasının yasak olduğunu ortaya koymak için kullanılmaktadır (North, 2010: 9-11). Benzer bakış açısıyla Carden kurumları, oyunun kurallarını içeren ve insanların güdülerini yönlendiren formel kurallar, enformel normlar ve düzenleyici bir mekanizma olarak tanımlamaktadır (Carden, 2007: 5). Greif'e göre ise kurum, sosyal bir davranış düzeni oluşturmak için kurallar, inançlar ve normlardan meydana gelen bir sistemdir (Greif, 2006: 30).

Neale bir kurumun üç özellik ile tanımlanabileceğini belirtmiştir. İlk olarak, belirli bir sayıda insan grubunun olmasıdır. İkinci olarak, bu insan grubunun faaliyetlerinde tekrarlama, istikrar ve sonucun öngörülebilir olmasını sağlayacak kuralların varlığıdır. Son 
olarak ise, faaliyetleri ve kuralları açıklayan veya bunları gerekçelendiren ortak bakış açılarının bulunmasıdır (Neale, 1987: 1183).

Kurum kavramına yönelik olarak yukarıda yapılan açıklamalar arasında birçok farklılık göze çarpmaktadır. Bu farklılıkların bir araya getirilmesi noktasından hareketle kurum kavramını, bir arada yaşayan bireyler arasındaki davranışları, eylemleri, alışkanlıkları, gelenek ve görenekleri, değerleri ve inançları temsil eden formel ve enformel kurallar bütünü olarak tanımlamak mümkündür. Söz konusu kurallar belirli bir zaman aralığında toplumsal kabul görmekte ve kurum haline dönüşmektedir (Aktan \& Vural, 2006a: 8).

\subsection{Formel ve Enformel Kurumlar}

Enformel kurumlar bir grup içerisinde deneyimlerin 1şı̆̆ 1 altında gelişen kurallar olarak tanımlanırken, formel kurumlar siyasal eylemin dişarıdan topluma empoze ettiği kurallar olarak tanımlanmaktadır (Kasper \& Streit, 1998: 100).

Enformel kurumlar, kişilerin bireysel yaşantılarına yönelik ya da toplumsal yaşam için gerekli bazı kuralları benimsemeleri anlamına gelir. Bir grup içinde uyulması gereken kurallar da bu kapsam içine girmektedir. Formel kurumlar ile karşılaştırıldığında en önemli farklılık, dışarıdan bir otorite tarafından dikte edilen veya o otorite tarafından belirlenen kurallar olmayışıdır. Enformel kurumların özellikleri ise, kişisel veya kolektif öğrenme yolu ile ortaya çıkması, belli bir süreç içinde gelişmesi, kurallara uymak konusunda herhangi bir zorlamanın olmadığı gibi herhangi bir yasal ceza ya da yaptırımın da olmaması olarak belirtilebilir (Aktan \& Vural, 2006b: 66). Enformel kurumlar, geçmiş yaşantılardan elde edilen bilgilerin toplumsal olarak yeni kuşaklara aktarılması ile oluşmaktadır. Toplumda var olan insanlar arasındaki tekrarlanan etkileşimi organize etmek amacıyla ortaya çıkmış olan enformel kurumlar; formel kurumların uzantıları veya değişmiş halleri, toplum tarafindan onaylanmış davranış normları ve içsel davranış standartlarıdır (North, 2010: 56). Enformel kurumlara en iyi örnek olarak toplum içinde geçmiş yaşantıların gelecek nesillere aktarılması ile oluşmuş gelenek ve görenekler rahatlıkla gösterilebilir.

Bir otorite tarafindan belirlenen ve toplumsal yaşamda düzen sağlanması amacıyla oluşturulmuş kurallar bütünü olarak tanımlanan formel kurumlar ise siyasi (yasal) kurallar, ekonomik kurallar ve sözleşmelerden meydana gelmektedir. Formel kurumların özelliklerine bakıldığında, bireyin dışında gerçekleşen genellikle bir otorite tarafından konulmuş kurallardan oluştuğu görülmektedir. Bu kurallara uymamanın cezai yaptırımı mevcut olup, uygulanması için de belirli bir maliyetin yapılması zorunludur. Ancak hem enformasyon yetersizliği hem de idari maliyetlerin varlığı dolayısıyla bu kurumların etkinliği tartışmaya açıktır (Aktan \& Vural, 2006b: 68). Formel kurumları enformel kurumlardan ayıran en önemli özellik, topluma empoze edilen ve toplumu şekillendiren kuralların siyasi irade tarafindan belirlenip, kanun yolu ile meşrulaştırılarak uygulamaya konmasıdır. Bu nedenle enformel kurumlar, siyasal karar alma sürecine ve hükümetlere göre değişkenlik gösterebilir. Ancak bu durum hükümetlerin formel kurumların sahibi olduğu anlamına gelmemektedir (Kasper \& Streit, 1998: 109-110). 
Toplum içinde bir düzenin oluşturulabilmesi için hem formel hem de enformel kurumlara gereksinim duyulmaktadır. Sadece geçmiş yaşantılardan deneme-yanılma veya tecrübe yolu ile elde edilen enformel kurumlar toplum içindeki bireyler arasında sorunsuz bir ilişki kurulması için yeterli olmayabilir. Bu nedenle toplum düzenini tesis etmek amacıyla enformel kurumların dışında insan aklı ile bir otorite tarafından oluşturulmuş kurumlara da gereksinim duyulması kaçınılmazdır (Aktan \& Vural, 2006b: 68).

\subsection{Kurumların İşlevleri}

Kurumların sahip olduğu işlevlere bakıldığında ise önceliği etkili koordinasyon ve güven almaktadır. Kurumun bir görevi, insan etkileşimi sürecinin karmaşık yapısını daha anlaşılır ve daha öngörülebilir hale getirmesidir. Bu karmaşıklığın giderilmesiyle birlikte farklı bireyler arasındaki etkileşim güçlük çekmeden sağlanabilir. Kurumlar dünyanın karmaşıklığını azaltarak, bireylerin üstüne düşen görevlerin basitleştirilmesinde önemli bir işlev görürler. Aynı zamanda kurumlar bireyleri, yaşantıları boyunca karşılaştıkları tatsız sürprizler, karmaşık ve şaşırtıcı durumlarla karşı karşıya kalmaktan önemli ölçüde korumaktadır. Güven ise, girişimci ve yaratıcı olmak ve yeni fikirler için başkalarını teşvik etmek gibi konularda bireylere bir dayanak oluşturmaktadır (Buchanan \& Di Pierro, 1980: 699, Aktan \& Çoban, 2007: 6).

Kurumların bir diğer işlevi ise güç ve tercihler üzerindeki etkisidir. Potansiyel anlaşmazlıklar sadece bireylerin özgürlük adı altında yaptıkları davranışlardan değil insanların birlikte çalışmalarından da meydana gelebilmektedir. Bireylerin zenginlikleri veya sahip oldukları karizma diğer bireyler ile olan ilişkilerinde kendilerine bir güç sağlayabilir. Bu durumu bir örnekle açıklamak gerekirse; fakir bir insan hayatta kalabilmek için paraya dolayısıyla bir işe gereksinim duyar. Zengin bir kişi için ise bu kişiyi işe almak oldukça kolaydır. Bu durumda, çalışmak zorunda olan fakir bireyin gözünde işveren güçlü bir konuma gelmektedir. Bu örnekte olduğu gibi eğer bireylerin başka bir alternatifi yok ise güç ilişkisi ortaya çıkmış olur. Alternatifler arasındaki tercihler, insanları özgür kılar. Alternatiflerin olmadığ 1 durumlarda tercihlerden bahsetmek mümkün değildir. Bu noktadan hareketle kurumlar, diğer insanların özgürlüğünü kısıtlayacak şekilde kullanılan gücün sınırlandırılmasını sağlamaktadır. Gücün sınırlandırılması ile benzer şekilde olan bireysel özerkliğin korunması ise kurumların bir diğer işlevidir. Dışarıdan gelen aşırı müdahalelerden (diğer insanların ellerindeki gücü aşırı kullanılması gibi) bireyleri korumak kurumların işlevleri arasında yer almaktadır. Özel mülkiyetin tesis edilmesi ve korunması, kurumların bireysel özerkliğin korunması adına en iyi örneklerinden birini temsil etmektedir. Kurumların en önemli işlevlerinden birisi de anlaşmazlıkların önlenmesi ve çözümüdür. Kurumlar, kişiler arası ve gruplar arası anlaşmazlıkların azaltılmasına yardımcı olur. Kurumlar bireyler arasındaki anlaşmazlıkların nasıl daha az maliyetle, daha az şiddetle ve nasıl diğer bireylerin özgürlük sınırlarını ihlal etmeden sağlanması amacına hizmet etmektedir (Kasper \& Streit, 1998: 118-122). 


\section{3. İnovasyon, İnovasyon Politikaları ve Kurumlar}

\section{1. İnovasyon Kavramı}

İnovasyon terimi, Latince kökenli innovatus (yenilemek ya da değiştirmek) kelimesinden türetilmiş olup alışıldık veya gelenekselden farklı olarak yeni bir şeyin ortaya çıkmasını nitelemektedir (Turanlı \& Sarıdoğan, 2010: 14). İktisadi ve modern anlamda inovasyonun kullanımı ise J.A. Schumpeter tarafından ortaya atılmıştır. Schumpeter en basit hali ile inovasyon kavramını, yeni bir üretim fonksiyonun tesis edilmesi olarak tanımlamaktadır. Söz konusu üretim fonksiyonu ise faktörlerin miktarının değişmesi halinde ürün miktarının da değişeceğini ifade etmektedir. Fakat, faktörlerdeki değişimin aksine üretim fonksiyonunun yapısında bir değişme olursa bu durumda inovasyon ortaya çıkmış demektir. Schumpeter tarafindan yapılan inovasyon tanımı yalnızca üretim fonksiyonunu değil yeni bir mal, yeni bir organizasyon şekli veya yeni pazarlara açılmak gibi kavramları da içermektedir (Schumpeter, 1939: 84).

Oslo Kılavuzunda ise inovasyon; iş yöntemlerinde, işyeri organizasyonunda veya dış ilişkilerde, yeni veya önemli ölçüde geliştirilmiş ürün (mal veya hizmet) veya süreç, yeni bir pazarlama metodu veya yeni bir örgütsel metodun uygulanması olarak tanımlanmıştır. $\mathrm{Bu}$ noktada bir inovasyon için minimum koşul; ürün, süreç, örgütsel metot veya pazarlama yönteminin firma için yeni ( $y a$ da önemli ölçüde geliştirilmiş) olmasıdır. İnovasyon faaliyetleri ise yeniliklerin uygulanmasına yol açan veya yol açması öngörülen tüm bilimsel, teknolojik, örgütsel, mali ve ticari adımlardır. Bazı inovasyon faaliyetlerinin kendileri yenilikçi (inovatif) iken bazı faaliyetler, yenilikçi olmamakla birlikte inovasyon uygulamaları için gereklidir. Öte yandan inovasyon faaliyetleri Ar-Ge'yi de içermektedir (OECD, 2005: 46-47).

İnovasyon; bir fikrin, pazarlanabilir bir ürüne, yeni bir üretim yöntemine veya yeni bir toplumsal hizmete dönüştürülme sürecidir. Aynı zamanda bu kavram mevcut problemler için yeni çözümlerin üretilmesini ve gerek toplumsal gerekse de bireysel ihtiyaçların karşılanmasını ifade etmektedir (EC, 1995: 2-8). Bununla birlikte her ne kadar inovasyon faaliyetlerinin firma karlılığını artırmak amaçlı yapıldığı ön planda olsa da söz konusu inovasyonun yeni bir ürün haline getirilerek ticarileştirilmesi yalnızca firma açısından bir getiri sağlamamaktadır. Bu noktada ortaya konulan yenilik gerek ülke sınırlarında gerekse de dünya genelinde bir fayda ortaya çıkarmaktadır. İktisadi anlamda ise yenilik üreten firma, rekabet üstünlüğü sağlayarak karlılığını artıracaktır. Bu rekabet üstünlüğünün sadece firma özelinde değil aynı zamanda ülke ekonomisine de pozitif bir katkı sağlaması muhtemeldir. Ancak inovasyon süreci göz önüne alındığında tüm sonuçların başarılı olacağını söylemek doğru bir ifade değildir. Böyle bir durumda ise yenilik üretmek için harcanan tüm kaynaklar boşa gitmiş olacaktır (Turanlı \& Sarıdoğan, 2010: 71-72). Dolayısıyla gerek firma risklerinin minimize edilmesi gerekse de toplumsal refahın artırılması adına ülkeler birtakım inovasyon politikaları ile yenilik sürecinin desteklenmesine katkıda bulunmaktadır. 


\section{2. İnovasyon Politikaları ve Kurumlar}

İnovasyon politikası, hükümetlerin inovasyon sürecini etkilemek için kurumları ve hedef grupların davranışlarını değiştirerek veya kontrol ederek almış olduğu önlemler şeklinde ifade edilebilir. Bununla birlikte söz konusu politikaların etkisi, inovasyon sürecinde yer alan aktörler ve kurumlar arasındaki müzakerelerin bir sonucu olduğu söylenebilir ( $\mathrm{Li}, 2013: 28)$. Bu noktada inovasyon politikaları, kamu idareleri tarafindan inovasyon sürecini etkileyen tüm faaliyetler olarak ifade edilmektedir. Kamu idareleri, inovasyon süreçlerini etkilemek için inovasyon politikalarını bir araç olarak kullanmaktadır. Politika araçlarının seçimi, politika oluşturmanın bir kısmını teşkil etmekte iken kendi başlarına araçlar, politika uygulamasının bir parçasını temsil etmektedir. İnovasyon politikasının nihai hedefleri siyasal süreç içinde belirlenmektedir. Söz konusu hedefler iktisadi olabileceği gibi sosyal, çevresel ve toplumsal alanlar için de ortaya konulabilmektedir. İnovasyon politikası araçları ise çok kısa bir sürede nihai hedefleri etkileme amacını taşımamaktadır çünkü söz konusu araçlar sadece inovasyon sürecini etkileyebilmektedir. Kamu politika araçları, hükümet yetkilileri tarafından sahip olunan gücün sosyal değişimi etkileme veya destekleme amacıyla kullanılmasıdır. Söz konusu etkileme ve destekleme, politika amaçlarının oluşturulması ile istenen nihai hedefe ulaşmada nasıl bir yol izleneceğini belirlemede rol oynamaktadır (Borras \& Edquist, 2013: 1513$1515)$.

Günümüzde ekonomik büyümenin belirleyicisi ve ülkeler arasındaki refah düzeylerinin farklılaşmasını açıklayıcı olarak teknoloji ve inovasyona olan ilgi giderek artmaktadır. Ancak bu ilgi yeni olmamakla birlikte Klasik iktisatçılardan günümüze kadar devam eden bir süreci kapsamaktadır. Bu süreç içerisinde gerek içsel gerekse de dişsal bir faktör olarak görülse de inovasyon önemli bir yer tutmaktadır. İnovasyon ve ekonomik büyüme arasındaki ilişkiyi kapsamlı bir şekilde ortaya koyan ilk iktisatçılardan birinin Joseph A. Schumpeter (1939) olduğu rahatlıkla söylenebilir. Schumpeter (1939) inovasyonu, yeni bir üretim fonksiyonu olarak tanımlamaktadır. Bununla birlikte Schumpeter tarafından yapılan inovasyon tanımı yalnızca üretim fonksiyonunu değil yeni bir mal, yeni bir organizasyon şekli veya yeni pazarlara açılmak gibi kavramları da içermektedir (Schumpeter, 1939: 84). Schumpeter'in ardından Robert M. Solow (1956) Neoklasik büyüme modeline teknoloji kavramını ekleyerek önemli bir katkı sağlamıştır. Solow, ekonomik büyümenin emek ve sermaye faktörleri dışında kalan kısmını teknolojik gelişmeyle açıklamakta ve söz konusu teknolojik gelişimin, üretimde ciddi bir artışa neden olacağını vurgulamaktadır (Solow, 1956: 85). Teknolojik gelişmeyi dışsal bir faktör olarak gören Neoklasik büyüme modeline tepki olarak Paul M. Romer $(1986,1990)$ öncülüğünde içsel büyüme modelleri ortaya konmuştur. Romer modelinde teknolojik yenilikler, uzun dönemli büyümenin itici gücü olarak belirtilmektedir. Söz konusu teknolojik yeniliklerin ortaya çıkması ise -en önemli girdisi bilgi olan- Ar-Ge faaliyetleri ile açılanmaktadır (Romer, 1990; 1986).

Ülkeler arasındaki refah düzeylerinin farklılaşmasını açıklayan görüşlerden bir diğeri de kurumsal yaklaşımdır. Bu hipoteze göre bazı toplumlar beşeri sermaye, teknoloji ve makineleşmeye yönelik yatırımları çeken iyi kurumlara sahiptir. Bunun sonucunda ise bu 
ülkeler daha kolay bir şekilde ekonomik refahı sağlamayı başarabilirler. İyi kurumların üç temel özelliği bulunmaktadır. Bunlardan ilki, toplumun geniş bir kısmını kapsayan mülkiyet haklarının uygulanmasıdır. Mülkiyet haklarının varlığı ve korunması bireylerin yatırım yapmasını ve iktisadi hayatta rol almasını teşvik etmesi açısından önem arz etmektedir. İkincisi ise, toplumun elit tabakası olarak adlandırılan politikacılar ile diğer güçlü grupların topluma ait olan gelirleri ve yatırımları kendi çıkarları için ele geçirmelerinin önüne geçilmesidir. Son olarak, toplumun geniş bir kesimini kapsayacak şekilde firsat eşitliğinin sağlanması iyi kurumların temel özelliklerinden biridir. Fırsat eşitliğinin sağlanması durumunda bireyler özellikle beşeri sermayeye yatırım yapacak ve verimli iktisadi faaliyetlere olan katılımlarını artıracaktır (Acemoglu, 2003: 27).

Kurumlar; tasarruf, yatırım, çalışma, teknoloji, üretim ve değişim ile ilgili kararları etkileyerek iktisadi davranışlar üzerinde doğrudan ve dolaylı yollarla bir etkiye sahiptir. Aynı zamanda kurumlar, bir ülkenin iktisadi sınırları içinde devletin ticari politikaları, müdahale sınırları, piyasaların dış yatırımlara açılma derecesi ve bireysel faaliyet alanı gibi olgular üzerinde önemli derecede etkin bir rol oynamaktadır. Dolayısıyla ekonomik büyüme modellerinin oluşturulmasında ve analizinde, büyümenin belirleyicisi olarak ele alınan değişken veya değişkenler kurumların ve kurumsal yapıların etkisi altında şekillenmektedir. Mülkiyet haklarının nasıl tanımlandığı, kurumların kalitesi, sosyal sermaye ve siyasal ve hukuksal yapı ile ilgili olan kurumlar, iktisadi kararların alınmasında temel belirleyicilerdendir. Bu noktadan hareketle kurumlar, iktisadi faaliyetlerin ve iktisadi büyümenin temel belirleyenlerini ve büyüme analizinin odaklanması gereken temel noktayı oluşturmaktadır (North, 2010; Biber, 2010: 4).

İnovasyon sistemi temelinde, önemli bileşenler olarak kurum (institutions) ve kuruluşları (organizations) içermektedir. $\mathrm{Bu}$ kuruluşlar, diğer firmalar (tedarikçiler, müşteriler, rakipler vb.) veya firma niteliği taşımayan (üniversiteler, araştırma enstitüleri, bakanlıklar vb.) kuruluşlar olabilmektedir. Bununla birlikte bu kuruluşların davranışları; kanunlar, kurallar, normlar ve adetler gibi inovasyonu teşvik eden veya engeller oluşturan kurumlar tarafindan şekillenmektedir. Dolayısıyla bu kurum ve kuruluşlar, bilginin ortaya konulması ve ticarileşmesi açısından sistemin önemli birer bileşenidir (Edquist, 2005: 182).

İnovasyon ve kurumlar arasındaki ilişkiyi gerek formel gerekse de enformel faktörler açısından incelemek mümkündür. Bu noktada, iktisadi yaşantıyı ve piyasa oyuncularının davranışlarını etkilemesi muhtemel olan regülasyon politikaları formel kurumlar açısından, inovasyonun ortaya konulması ve yayılmasında önemli etkilere sahip olan sosyal sermaye ise enformel kurumlar açısından ele alınabilir. Her iki kurum da inovasyon sürecinde firmaların veya toplumda yaşayan bireylerin davranışlarını etkileme/değiştirme gücüne sahiptir.

\subsection{1. İnovasyon Politikaları ve Formel Kurumlar}

İnovasyon; firma ve tüketiciler, firmalar ve diğer organizasyonlar gibi firmaların içinde yer aldığı etkileşimlerin bir sonucudur. Etkileşimler bu aşamada, iktisadi ve sosyal bağlamda meydana gelen ve toplumsal yapıya entegre edilmiş bir süreci ifade etmektedir. 
Kurumlar ve regülasyonlar, söz konusu etkileşimleri ve inovasyon sürecinin toplumsal entegrasyonunu içeren oyunun kurallarıdır. $\mathrm{Bu}$ nedenle kurumlar ve regülasyonlar, etkileşimleri ve toplumsal entegrasyonun yer aldığı yolu şekillendirecektir. Bir başka deyişle inovasyon, herhangi bir toplumun kendi kendine organize ettiği oyunun kurallarına bağlı olan sosyal bir olgudur (Borras \& Edquist, 2013: 4). Bu noktada kurumlara olan bakış açısı; oyunun kurallarını koyma veya oyun alanını tanımlayan formel yasalar oluşturma şeklinde açıklanabilir (Hwang \& Powell, 2005).

Regülasyonların inovasyon süreci üzerindeki etkisi ise regülasyon yapılan alanlara göre farkl1lık göstermektedir. Bu noktada uygulamaya konulan düzenlemeleri; ürün piyasası, işgücü piyasası, sermaye piyasası düzenlemesi ve fikri mülkiyet haklarının korunması şeklinde bir ayrıma tabi tutarak incelemek yerinde olacaktır.

Ürün piyasası düzenlemelerinde inovasyon sürecini etkileyen en önemli unsur, tekelcilik karşıtı (Anti-trust) politikalardır. Tekelcilik karşıtı politikalar, piyasa gücünün ve piyasa yoğunlaşmasının azaltılmasını böylelikle rekabetin artmasını amaçlayan politikalardır. Rekabetin artması da firmaların inovasyona yönelmelerini teşvik edici bir etkiye sahiptir. Her ne kadar literatürde rekabet düzeyinin büyük ölçüde inovasyonun temel belirleyicilerinden biri olduğu (Arrow, 1962; Nickell, 1996; Blundell vd., 1999) kabul görse de rekabet ve yenilik arasındaki ilişki ile ilgili olarak farklı sonuçlar (Schumpeter, 1942; Aghion vd., 2005) ortaya koyan çalışmalar da bulunmaktadır. Bununla birlikte sıkı tekelcilik karşıtı yasalar, -genellikle inovasyon ile pozitif ilişkili olan- firma büyüklüğü noktasında inovasyon üzerinde negatif bir etkiye yol açabilmektedir. Ürün piyasası düzenlemelerinde bir diğer önemli unsur, başlangıç maliyetleri (start-up costs) ile ilgili olan piyasaya giriş düzenlemeleridir. Başlangıç maliyetleri, bir faaliyete başlamak için devlet tarafından konulan şartların yerine getirilmesini ifade eden ve daha çok batık maliyet olarak kabul edilen maliyetlerdir. Söz konusu maliyetlerin yüksek olması, girişimcilerin piyasaya girmelerini zorlaştırdığı ve dolayısıyla inovasyon süreci önünde bir engel olduğu kabul görmektedir (Barbosa \& Faria, 2011: 1158-1159).

İşgücü piyasası düzenlemeleri; işe alma ve işten çıkarma, ücret oranları, işsizliğe yönelik politikalar gibi birçok mevzuata ilişkin unsurları kapsamaktadır. Bu düzenlemeler işgücü piyasasını etkilemeyi amaçlasa da doğal olarak bu düzenlemelerin inovasyon üzerinde de bir etkiye sahip olacağını söylemek mümkündür. Örneğin, eğitim ve öğretim politikalarının belirli bir ülkedeki beșeri sermaye stokunu değiştirerek inovasyon üzerinde pozitif bir etki sağlaması beklenebilir. Öte yandan işgücü piyasası düzenlemeleri arasında istihdamın korunması, inovasyonu etkileyen bir faktör olarak dikkat çekmektedir. Bununla birlikte katı istihdam düzenlemelerinin bazı zıt etkileri de bulunmaktadır. Öncelikle katı olarak nitelendirilebilecek işe alma ve işten çıkarma düzenlemeleri, sendikaların pazarlık gücünü artırması nedeniyle firmaların, inovasyon gerçekleştirildikten sonra ücret ayarlamalarını veya personel sayısını azaltma veya personelin yeniden tahsisini gerektiren yeni teknoloji ayarlamalarını yapmalarını daha zor hale getirmekte ve hatta firmaları, yeni teknoloji deneyimlerinden vazgeçirmektedir. Öte yandan katı işten çıkarma düzenlemelerinin işverenler için eğitime yatırım yapmalarını teşvik edici bir etkiye sahip olduğu ve böylelikle eğitime yapılan yatırımların çalışanların verimliliğini ve 
motivasyonunu artıracağı zit bir etki olarak ileri sürülmektedir (Barbosa \& Faria, 2011: 1159-1160). Bununla birlikte finansal regülasyonlar ise yeni firmaların oluşturulması, kurumsal yönetişim yapıları ve iflas kanunları için yasal gereksinimleri tanımlamaktadır. Söz konusu düzenlemeler birçok nedenden ötürü inovasyon sistemi için temel teşkil etmektedir. Şeffaf ve kanunların uygulandığı koşullarda rekabetçi piyasa fiyatlarında sermayeye erişmek yenilikçi firma (yeni başlamış veya daha önce kurulmuş) açısından kilit bir rol oynamaktadır. Aynı zamanda bu düzenlemeler, sermaye için uygun fiyatı ve kuralları tanımlamasının yanısıra firmaların yaşam döngüsünün (yeni firmaların kurulması, iflas, miras vb.) temel adımlarındaki koşullar ve sorumluluklar hakkındaki belirsizlikleri azaltarak yatırımlar için teşvik sağlamaktadır (Borras \& Edquist, 2013: 7-8).

İnovasyon süreci açısından bir diğer önemli kurum ise fikri mülkiyetin korunmasıdır. Telif hakları ve patentler gibi fikri mülkiyet haklarının amacı; firmaların araştırma yatırımlarının sosyal getirilerinden daha yüksek bir fayda elde etmesine izin vererek inovasyonun teşvik edilmesidir (Williams, 2010: 1). İnovasyonun teşviki ve sürekli hale getirilmesi, fikri mülkiyet düzenlemeleri ve rekabeti koruma amacıyla konulan kuralların ortak noktasıdır. Fikri mülkiyet düzenlemelerin yanında hukuki olarak da bir korumanın sağlanması, firmalar tarafindan yapılan araştırma yatırımlarının garanti altına alınmasını sağlar. Söz konusu rekabeti koruyucu kurallar sayesinde ekonomik düzen içinde rekabetin sürdürülmesi ise hem hukuki koruma ile elde edilen tekelin kötüye kullanılmasını önler hem de ekonomik aktörleri, yeni ürün ve yöntemler geliştirme kapsamında rekabet etmeye teşvik eder. $\mathrm{Bu}$ noktadan hareketle, serbest piyasa koşulları altında kar amacıyla hareket eden aktörlerin yeni teknolojilere yatırım yaparak birbirleri ile rekabet etmeleri ve rekabet güçlerinin artması açısından fikri mülkiyetin korunması önem arz etmektedir (Boztosun, 2007: 5).

Kurumlar; kanunlar, kurallar, düzenlemeler ve politikalar gibi iktisadi teşvikleri etkileyen dolayısıyla beşeri sermaye, fiziksel sermaye ve teknolojiye yapılan yatırımları teşvik eden bir unsur olarak ele alınabilir. Bu noktada iktisadi faaliyetler içinde kurumların en temel rolü, işlem maliyetlerini azaltmasıdır. Eğer kurallar ve düzenlemeler; açık, şeffaf ve piyasa mekanizmasını daha verimli çalışır hale getirecek şekilde dizayn edilirse bu durum piyasanın daha düzenli halde çalışmasını ve gelecekteki yatırımların teşvik edilmesini sağlayabilecektir. Şeffaf kuralların, düzenlemelerin, kanunların ve politikaların varlığı ise iktisadi faaliyetlerden doğan kazançların eşit olarak dağıtılmasına da katkı yapabilecektir (Rauf, 2009: 34). Söz konusu formel kurumların yanında kurumlar ve inovasyon arasındaki ilişkiyi tanımlayan ve açıklamaya çalışan bir diğer unsur enformel kurumlardır.

\subsection{2. Ínovasyon Politikaları ve Enformel Kurumlar}

Enformel kurumlar, toplum içindeki oyuncuların davranışlarını etkileme gücüne sahiptir. Özellikle iktisadi seçimler ve davranışlar, toplumdaki tüm kurumlar ve kurumsal düzenlemeler ile şekillenmektedir (Acemoglu vd., 2004). Birçok yönden normların, gelenek ve göreneklerin oluşturduğu enformel kurumlar, iktisadi çıktıları etkileyebilmektedir. Enformel kurumlar ile inovasyon arasındaki ilişkiyi beşeri ve sosyal sermaye açısından incelemek mümkündür. Enformel kurumlar, son dönemlerde ek bir üretim faktörü olarak 
kabul edilen sosyal sermayenin üretiminden sorumludur. Sosyal sermaye, enformel kurumların etkisini ortaya koymakla birlikte sosyal bağların değer yaratan yönünü işler hale getirmeye yardımcı olmaktadır (Rauf, 2009: 34).

Sosyal sermaye; toplumu oluşturan bireyler arasındaki koordinasyonu ve etkileşimleri geliştiren güven, normlar ve ağlar gibi sosyal kuruluşların özellikleri olarak ifade edilebilir (Putnam vd., 1993: 167). Coleman (1988) ise sosyal sermayenin tanımının sahip olduğu fonksiyonlara göre yapılabileceğini ifade etmektedir. Ona göre sosyal sermaye, tek bir varlık olmayıp genel olarak iki temel unsuru içeren farklı varlıkların bir çeşididir. Öncelikle bu varlıkların her biri toplumsal yapının belirli özelliklerini içermekte ve diğer yandan yapı içindeki aktörlerin -gerek bireylerin gerekse şirketlerin- davranışlarını şekillendirmektedir (Coleman, 1988: 98).

Sosyal sermaye ve toplumsal fayda arasındaki ilişkiyi ortaya koyan öncü çalışmalardan biri Putnam vd., (1993) tarafindan yapılmıştır. Putnam vd., (1993) çalışmasında, İtalya'da yerel yönetimler arasındaki performans farklılıklarını açıklamaya çalışmakta ve bu farklılıkların gerekçesini sosyal sermaye düzeyine dayandırmaktadır. Aynı şekilde sosyal sermayenin, toplumsal güvene dayalı ilişkilerin ve işbirliğine yaptığ katkılardan dolayı inovasyon sürecinde de etkili olduğunu ileri sürmektedir (Putnam vd., 1993). Sosyal sermayenin en önemli çıktısı toplumsal güvenin sağlanmasıdır. Güven, inovasyon süreci açısından önem arz eden enformasyon paylaşım maliyetleri, işlem maliyetleri ve uygulama maliyetlerini azaltıcı etkilere sahiptir. Genel olarak sosyal sermayenin inovasyon üzerindeki etkisi dolaylı ve doğrudan olmak üzere iki şekilde açıklanabilir. Toplumun tüm üyeleri arasında güven, karşılıklı ve iyi niyetli duygular ile oluşturulmuş daha geniş bir sosyal sermaye, yenilikçi birimlerin bir araya gelmesine ve risklerin üstlenilmesine yardımcı olmaktadır. Bu durum, firma düzeyindeki sosyal sermaye ile dolaylı yönden ilişkili ve iletişim ağlarının (networks) geliştirilmesine yardımcı bir etki olarak ifade edilebilir. Öte yandan doğrudan etki ise piyasaya ilişkin enformasyon, knowhow, firmalar arasındaki fikir alışverişleri ve iletişim ağlarında görülebilir (Rauf, 2009: 3436).

Beşeri sermaye kavramı ise, kişisel ve sosyal gelişime katkı sağlamakla birlikte iktisadi anlamda refahın artırılmasını kolaylaştıran bilgi ve beceri gibi bireylerin sahip olduğu yetenekler olarak tanımlanmaktadır (OECD, 2001: 17). Genel anlamda insanların sahip olduğu bilgi, uzmanlık ve yetenekler olarak ifade edilen beşeri sermaye; bireylerin, kuruluşların ve toplumların rekabet avantajlarının önemli bir kaynağı olarak görülmektedir (Coleman, 1988; Gimeno vd., 1997).

Beşeri sermaye ve toplum arasındaki ilişkinin ortaya konulmasında kabul gören temel düşünce; daha iyi eğitim almış, daha fazla iş deneyimine sahip ve yeteneklerini geliştirmek için zaman, enerji ve kaynaklara daha fazla yatırım yapan kişilerin kendilerine daha yüksek fayda sağladığıdır. Söz konusu elde edilen bireysel faydanın aynı zamanda toplumun genel refahına da katkı yapması mümkün olabilmektedir (Dakhli \& Clercq, 2004: 111). Beşeri sermayenin ülkelerin gelişmişlik seviyesine yapmış olduğu katkılar büyüme modellerine dâhil edilerek ele alınmıştır. İnovasyon politikaları noktasında ise daha çok 
eğitim ve sahip olunan meslek veya yetenekler açısından önem kazanmaktadır. İnovasyon açısından beşeri sermaye, yeni bir bilgi ve teknolojiyi kendine katmak, özümsemek ve geliştirmek açısından bir firmanın sahip olduğu kapasitenin yansımasıdır. Bu aşamada, daha fazla yeni bilgi ve teknolojinin özümsenmesi, firmaların beklenenden daha fazla inovasyon eğilimi içinde olmasına yola açmaktadır (Almeida vd., 2014: 88-91). Bununla birlikte firma düzeyinde işbaşı eğitim ve öğretim yoluyla beşeri sermayeye yapılacak yatırımlar, verimliliği ve rekabet edilebilirliği artıracaktır. Söz konusu verimlilik düzeyinin artırılması toplumsal verimliliği de pozitif yönde etkileyecektir. İktisadi faaliyetlerdeki genel büyümenin devamında bu büyümenin desteklenmesi adına yeni süreç ve inovasyona olan ihtiyaç daha da artacaktır. Dolayısıyla bir ülke içindeki beşeri sermaye düzeyi yükseldikçe ülkenin inovasyon düzeyi de yükselecektir (Dakhli \& Clercq, 2004: 122).

İnovasyon ve kurumlar arasındaki ilişkiyi teorik düzeyde ele alan çalışmaların yanında bu ilişkiyi ortaya koyan ampirik çalışmalar da bulunmaktadır. Ancak kurumlar ve ekonomik büyüme arasındaki ilişkiyi araştıran birçok ampirik çalışma literatürde yer almasına rağmen kurumlar ve inovasyon arasındaki ilişkiyi açıklamaya yönelik ampirik çalışmaların sınırlı düzeyde kaldığı görülmektedir.

Carlsson ve Jacobson (1997), teşvik sağlama, çatışmalarda arabuluculuk yapma, bilginin kullanımını koordine etme ve belirsizlikleri azaltma noktasında kurumların inovasyonu uyarıcı bir etkiye sahip olduğunu ileri sürmektedir. Srholec (2011) çalışmasında inovasyonun birçok farklı düzeye sahip bir olgu olduğunu ileri sürmektedir. Bu noktadan hareketle inovasyonun belirleyenlerini ortaya koymak için yapılacak analizlere kurumları da içeren üst düzey faktörlerin (dışsal/çevresel faktörler) de dâhil edilmesi gerektiğini savunmaktadır. Analiz bulgularında ise demokratik kurumlar ile inovasyonun ilişkili olduğunu ifade etmektedir. Blind (2012) ise çalışmasında regülasyonlar ile inovasyon arasındaki ilişkiyi ortaya koymaya çalışmıştır. Bu noktada kurumsal yapı içerisinde bulunan regülasyonların inovasyona etkisi iktisadi, sosyal ve kurumsal regülasyonlar olarak ayrı ayrı ele alınmıştır. İktisadi regülasyonlar kapsamında -fiyatların esnek olduğu koşulda- fiyat regülasyonlarının ve rekabeti artırıcı düzenlemelerin inovasyon üzerinde pozitif bir etki yaptığını ancak pazara giriş düzenlemelerinin negatif bir etkiye sahip olduğunu; sosyal regülasyonlar kapsamında işgücünün korunması düzenlemelerinin negatif ancak ürün ve müşteri güvenliğine yönelik düzenlemelerin inovasyon üzerinde pozitif bir etkiye sahip olduğunu; kurumsal regülasyonlar kapsamında ise fikri mülkiyet hakkı düzenlemelerinin inovasyon üzerinde pozitif bir etkiye sahip olduğunu vurgulamaktadır (Blind, 2012: 394396). Kurumlar ve inovasyon ilişkisini ortaya koyan bir diğer çalışmada ise Tebaldi ve Elmslie (2013), iktisadi kurumların kalitesi ile inovasyon arasında pozitif bir ilişki olduğunu ifade etmektedir. Endonezya'da faaliyet gösteren firmaların inovatif faaliyetler için gerekli finansmana erişim ve kurumların etkisinin araştırıldığı çalışmada ise Mahendra ve diğerleri (2015), yerel düzeyde daha yüksek kurumsal kalitenin inovasyon sürecine daha fazla katkı sağladığını belirtmektedir. Çalışmada aynı zamanda finansmana erişimde daha büyük engel yaşayan firmaların, inovasyon kapasitelerinin daha az olduğuna yönelik bazı kanıtlar bulunduğu ifade edilmektedir. Silve ve Plekhanov (2015) ise çalışmasında, iktisadi kurumlar, inovasyon ve büyüme arasındaki ilişkiyi analiz etmiştir. İmalat sanayinin ön planda tutulduğu çalışmada, güçlü iktisadi kurumlara sahip olan ülkelerin yenilik-yoğun 
sektörlerde daha fazla uzmanlaştığı ifade edilmektedir. Bunun yanında analiz bulguları, inovasyonun -yüksek kaliteli iktisadi kurumların varlığı doğrultusunda- uzun dönemde büyüme performansına önemli bir katkı sağlayacağı görüşünü desteklemektedir.

İnovasyon politikaları ve kurumlar arasındaki ilişkiye genel olarak bakıldığında, uygulamaya konulan düzenlemelerin veya toplumu oluşturan dinamiklerin ortak bir paydada buluşması gerekliliği ortaya çıkmaktadır. İnovasyon süreci ve ulusal inovasyon sisteminin oluşturulması aşamasında bu süreçte yer alan tüm aktörlerin katılımı ve ortak hareketi kilit bir rol oynamaktadır. Dolayısıyla sadece firmaların dâhil olduğu bir süreç, inovasyonun gerçekleştirilmesinde yeterli olmayacaktır. Bu noktada öncü bir kurum olarak devlet, inovasyon sürecine dahil olan tüm aktörleri bir araya getirebilmek adına gerek formel gerekse de enformel kurumların oluşturulması ve uygulanması açısından önemli bir rol üstlenmektedir.

\section{Yenilikçi Kamu Alımları ve Kurumlar}

Dünya genelinde birçok hükümet, verimlilik artışını sağlamak ve yüksek yaşam standartlarına ulaşmak için inovasyon faaliyetlerini teşvik etme yoluna gitmektedir. Böyle bir amaç göz önüne alındığında, hayat standartlarının yükseltilmesi ve geliştirilmesinde temel faktörün verimliliğin artırılması olduğu ifade edilebilir. Bu noktadan hareketle özellikle inovasyonun gerçekleştirilmesine yönelik kamu politikaları ön plana çıkmaktadır (Globerman, 2012: 8).

İnovasyon faaliyetlerinin geliştirilmesine yönelik kamu politikaları, özellikle hükümetlerin satın alma ve finansman sağlama potansiyelinin yüksek olması nedeniyle önemli bir rol üstlenmektedir. Daha önceleri teknolojinin geliştirilmesi ve inovasyon sürecinin tamamlanabilmesi için arz yönlü politikalar tercih edilirken günümüzde talep yönlü inovasyon politikaları önem kazanmıştır. Talep yönlü inovasyon politikalarının öne çıkmasını sağlayan önemli politika araçlarından biri, kamu alımlarıdır. Ülkelerin sahip olduğu GSYH'nın önemli bir kısmı kamu alımlarına ayrılmaktadır. Dolayısıyla, gerçekleştirilen kamu alımlarının inovasyon faaliyetlerinin artırılması ve teşvik edilmesinde önemli bir rol üstlenebileceği rahatlıkla söylenebilir.

Teknoloji geliştirme veya inovasyona yönelik olarak yapılan kamu alımları literatürde farklı kavramlar ile açıklanmaktadır. Bu kavramlar; hâlihazırda piyasada mevcut olmayan ancak belirli bir süre içerisinde geliştirilebilecek ürün veya sistemlerin alımını ifade eden kamu teknoloji alımları (Public Technology Procurement) (Edquist \& Hommen, 2000: 5), ihtiyacın karşılanması için araştırma ve yenilik faaliyetleri gerektiren, hâlihazırda piyasada mevcut olmayan veya yeni özelliklere sahip olması gereken mal ve hizmetlerin alımını ifade eden inovasyon için satın alımlar (Procurement for Innovation) (EC, 2005: 9); hâlihazırda piyasada mevcut olmayan ancak belirli bir süre içerisinde kamu otoritesinin talebi doğrultusunda firmalar tarafından geliştirilebilecek yenilikçi ürünlerin satın alımını ifade eden yenilikçi kamu alımları (Innovative Public Procurement) (Hommen \& Rostam, 2009: 20); yenilikçi sözleşmeye bağlı satın alımların uygulama ve prosedürlerindeki 
yenilikçi yaklaşımları ifade eden yenilikçi satın alımlar (Innovative Procurement) (National ICT Research Directors Forum, 2006: 14) olarak belirtilebilir.

Kamu alımları ile ilgili olarak literatürde bulunan kavramlar farklılık gösterse de bazı ortak noktaları da içinde barındırmaktadır. Söz konusu kavramların üzerinde uzlaştığı nokta, inovasyon faaliyetlerinin teşvik edilmesinde bir kamu otoritesinin varlığıdır (Rolfstam, 2012a: 2-4). Yenilikçi kamu alımları kavramının net bir biçimde ortaya konulabilmesi için kamu alımı tanımlarında bir ayrımın yapılması gerekmektedir. Bu aşamada en basit şekilde kamu alımları; olağan kamu alımları ve yenilikçi kamu alımları olarak incelenebilir. Olağan kamu alımları, hâlihazırda mevcut ve satılmaya hazır olan temel ihtiyaç mallarının satın alınmasıdır. Bu noktada satın alım yapan kurum veya birimin, teklif verenlerden herhangi yeni bir ürün (inovasyon) talebi bulunmamaktadır. Dolayısıyla olağan alımların; kalem, kâğıt, havlu veya araç-gereç gibi söz konusu birimin faaliyetlerinde devamlılık sağlayan ürünlerin satın alınması olduğu söylenebilir (Edquist, 2015: 6). Yenilikçi kamu alımları ise iki farklı yaklaşım ile açıklanabilir. Bunlardan ilki, yeni ürünlerin (mal, hizmet, sistem) gelişimini teşvik için bir araç olarak gören yaklaşımdır. Diğeri ise, mutlaka yeni ürünler ortaya koyma hedefi olmaksızın inovasyon olanaklarını geliştirmek için yapılan girişimleri nitelemektedir (Lember vd., 2014: 14). Yenilikçi kamu alımlarını en basit haliyle; yeniliklerin ortaya konulması, geliştirilmesi, adaptasyonu ve yayılmasını uyaran herhangi bir kamu alım faaliyeti olarak tanımlamak mümkündür (Li, 2013: 70).

Kamu kurumlarının kendi işlevlerini gerçekleştirmek için ihtiyacı olan mal ve hizmetleri temin etmesi şeklinde tanımlanan kamu alımları, bir inovasyon politikası aracı olarak da kullanılabilmektedir. Bu satın alım geniş bir sektör aralığında meydana gelmekle birlikte inşaat, sağlık ve ulaşım (ek olarak savunma ve güvenlik) gibi alanlarda daha belirgin olarak ortaya çıkmaktadır. İnovasyon yönlü faaliyetler, kamunun satın alıcı rolde olduğu durumda piyasada henüz var olmayan mal veya hizmetlerin talep edilmesi yoluyla inovasyonun tetiklenmesi şeklinde ifade edilebilir (Georghiou vd., 2014: 2).

Yenilikçi kamu alımları, ulusal yenilik sistemleri içerisinde önemli bir yere sahiptir. Ulusal yenilik sistemi konusunda farklı tanımlamalar bulunsa da bunlar arasındaki ortak nokta inovasyonun geliştirilmesi için kurumlar (aktörler, unsurlar, öğeler) ve bu kurumlar arasındaki etkileşimin varlığını içeren bir yapının tanımlanmasıdır (Gregersen \& Johnson, 1997: 484; Nelson \& Rosenberg, 1993: 4; Lundvall, 1995: 2). Bazı araştırmacılara göre ulusal yenilik sistemi fikri mükemmel bir kurumsal mefhumdur (conception) (Nelson \& Nelson, 2002: 265). Ulusal yenilik sistemini oluşturan kurumlar ve bunlar arasındaki etkileşim Şekil 1'de gösterilmiştir. 
Şekil: 1

Ulusal Yenilik Sistemi Modeli

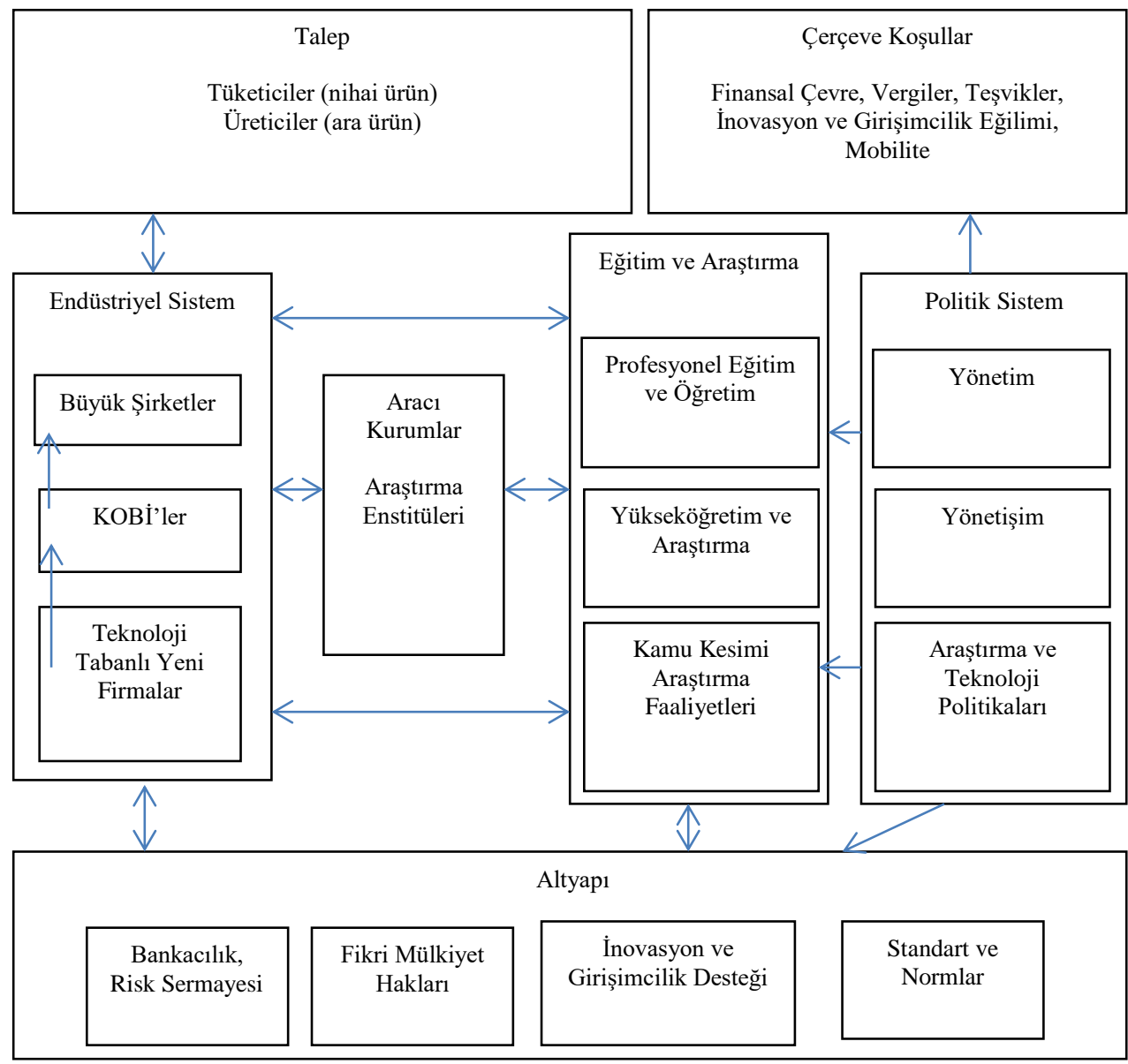

Kaynak: Kuhlmann \& Arnold, 2001: 2.

Ulusal yenilik sistemi birçok alt sistemin bir araya gelmesi ile oluşturulan bir karakteristiğe sahiptir. Bir ülkedeki politik sistem, eğitim ve araştırma, altyapı, endüstriyel sistem, aracı kurumlar ve süreçte ortaya çıkacak yeniliği tüketen ya da talep eden kurumsal yapıların olduğu bir alt sistemler bütünüdür. Sistemin temelini oluşturan bu kurumlar arasında oluşacak formel ve enformel etkileşimler sonucunda yeni teknolojilerin ve yenilikçi teknolojilerin ortaya çıkması ve yayılması gerçekleşecektir. Kurumların varlığı adeta sistemin yapı taşlarını oluşturmakta fakat sistemin dinamizmini ve üretkenliğini kurumlar arası etkileşim sağlamaktadır. Hiç şüphe yok ki kurumsal etkileşimlerin diğer ülkelere göre daha kolay gerçekleştiği ülkeler vardır. Regülasyonlar, vergiler, rekabet, fikri mülkiyet 
hakları gibi çerçeve politikalar kurumsal etkileşimi ve bilgi akışını kolaylaştırabilir ya da zorlaştırabilir (OECD, 1997: 13).

Ulusal yenilik sistemi içerisindeki yapıda yer alacak kurumlar bilgiyi/inovasyonu üreten, yayan ve kullanan kurumlar şeklinde değerlendirilebilir. Bu noktada sistem içerisinde yer alan firmalar, aracı kurumlar, araştırma kurumları gibi aktörlerin yanında kamu kurumları önemli bir yere sahiptir. Kamu kurumları sistem içerisinde bilgiyi üreten, kullanan ve yayılmasını sağlayan bir konumuna sahip olabilir. Devlet bizatihi kendisi ArGe faaliyetleri ile bilgi üretimine katkıda bulunabilir ya da çeşitli vergisel teşvikler, istisna ve muafiyetler ile özel sektör Ar-Ge faaliyetlerini yönlendirebilir, inovatif çözümlerin kullanımı yaygınlaştırabilir. Ayrıca kamusal hizmetlerin sunumu için gerçekleştireceği kamu alımları aracılığı ile hem yenilikçi fikirlerin bulunmasına hem de özel sektörün bu alandaki dinamizmine katkı sağlayabilir. Bu açıdan devlet, kamu alımları yoluyla ulusal yenilik sistemleri içerisinde yenilikçi çözümleri talep eden en temel kurumlardan biridir.

Yenilikçi kamu alımları, ulusal yenilik sistemleri içerisinde spesifik bir uygulama alanıdır. Kamu alımları ile ihtiyacı ya da sorunu gidermeye özgü bir hizmet gerçekleştirilmektedir. Kamu kurumları söz konusu ihtiyaç ya da sorunun ne olduğu konusunda uzmanlığa sahiptir fakat bu sorunun çözümünde tam bir uzmanlığa sahip olamayabilir. Kamu alımlarının nihai amacı belirli bir meblağ karşılığında birtakım hizmetleri gerçekleştirecek tedarikçiyi belirlemektir. Bazen yenilikçi çözümler, ihale sürecinden sonra ortaya çıkabileceğinden tedarik edilen ürün ya da hizmet konusunda belirsizlikler de olabilir. Yenilikçi kamu harcamaları böyle bir karakteristik özelliğe sahip olduğundan bu tür kamu alımları, kullanıma ya da satışa hazır ürün ve hizmetleri kapsayan olağan kamu alımlardan farklılaşmaktadır. Bu durum yenilikçi kamu alımlarını daha karmaşık ve etkileşimli bir süreç haline getirmektedir (Rolfstam, 2012b: 308).

Kurumsal yaklaşımın bakış açısıyla kamu alım süreçlerini de bir kurum olarak değerlendirmek mümkündür. Kamu alımları, temel aktör olarak devletin alıcı ve özel firmaların satıcı konumunda yer aldığı ve bu aktörler arasında formel ve enformel etkileşimin olduğu bir süreçtir. Bu süreç aynı zamanda ekonomik, sosyal, kültürel, yasal ve siyasi kurumlar ile de şekillenmektedir.

Ülkelerin ulusal yenilik sistemleri içerisinde yenilikçi kamu alımları öncelikle savunma ve askeri amaçlı olarak kullanılmaya başlanmış olsa da (Nelson, 1993), günümüzde sağlık, ulaşım, eğitim, altyapı, enerji gibi diğer alanlarda da kullanılmaktadır. Kamu alımını gerçekleştiren birim ihtiyaçların etkin ve düşük maliyetle gerçekleştirilmesini amaçlarken tedarikçi firmalar elde edecekleri karlar, sözleşme şartları, sorumluluklar gibi alanlara odaklanmaktadır. Tedarikçi firmalar açısından kamu alım sürecini yönetecek kuralların standart ve net olması gerekmektedir. Avrupa Birliği nezdinde AB Komisyonu tarafindan kabul edilen kamu alımları direktifi, kamu alım sürecinin kurallarını ortaya koyan yasal bir kurumdur. Bu direktife göre; kamu alım ihalelerinin açık bir şekilde ilan edildiği, tedarikçi firmalar arasındaki rekabeti ön plana çıkaran, yeterli finansal ve teknik kapasiteye sahip olmayan firmaları dışlayan, ihaleye başvuru için yeterli süreyi tanıyan bir süreç olduğu ifade 
edilmektedir. Aynı zamanda ülkelerin bu direktif doğrultusunda ulusal düzenlemelerini yapmaları öngörülmüştür (Rolfstam, 2012b: 309).

Yenilikçi kamu alımlarının kurumsal çerçevesinin oluşturulması beklenen faydaların gerçekleşmesi ve sürecin sağlıklı bir şekilde işlemesi için önem arz etmektedir. Bu kapsamda yenilikçi kamu alımlarında yenilikten kastedilen hususların ne olduğu, örneğin bir ürün ya da hizmetin sunum sürecindeki bir yenilik mi, üretim sürecindeki bir yenilik mi veya nihai ürün/hizmette bir yenilik mi olduğu açık bir şekilde ortaya konulmalıdır. Bununla birlikte olağan kamu alımları yöntemlerinde kullanılan ihale yöntemlerinden daha farklı ihale yöntemlerine de ihtiyaç duyulmaktadır. Gerek tanımlama aşamasında gerekse de ihale sürecinin yürütülmesi aşamasında devletin oyunun kurallarını ortaya koyması gerekmektedir. Dolayısıyla yasal düzenlemeler ile yenilikçi kamu alımlarının formel çerçevesi belirlenmeli, bunu gerçekleştirirken de özel sektör Ar-Ge faaliyetlerini teşvik edici, yenilikçi fikirlere önem veren, piyasadaki yenilikçi ve teknolojik ürünlere ilişkin rekabeti artırıcı bir çerçeve belirlenmelidir.

\section{Sonuç}

Kurumsal yaklaşım bir ülkedeki ekonomik hayatı değerlendirmede kurumların önemine değinmektedir. Süreçte ekonomik birimlerin aldığ 1 kararlarda toplumdaki gerek formel gerekse enformel kurumların etkili olduğu kabul edilmektedir. Başka bir ifade ile alınan ekonomik kararlar üzerinde kurumların belirleyici bir role sahip olduğu kabul edilmektedir.

Ülkelerin uluslararası rekabet gücü ve refah seviyesini belirleyen temel faktörlerin başında ülkelerin teknoloji ve yenilikçi çözümleri üretme kapasiteleri gelmektedir. Ülkedeki inovasyon düzeyinin artırılması için hem özel sektör hem de kamu sektörünün üstlenmesi gereken bir takım fonksiyonlar bulunmaktadır. Bu noktada özel sektörün yeniliklere açık, Ar-Ge faaliyetlerine önem veren, teknolojik gelişmelere yatırım yaparak bireysel ve toplumsal ihtiyaçların daha etkin bir şekilde karşılanmasını sağlayan bir yapıda olması gerekmektedir. Kamu sektörü de Ar-Ge faaliyetlerini destekleyen, kamusal ihtiyaçları etkin ve en az maliyetle karşılayan, özel sektörün yenilikçi faaliyetlerine hem yön veren hem de destekleyen bir yaklaşıma sahip olması gerekmektedir.

Toplumsal ihtiyaçların karşılanmasında en önemli aktör, devlettir. Devlet kamu alımları yoluyla bu fonksiyonunu gerçekleştirmektedir. Kurumsal yaklaşımın bakış açısıyla kamu alım süreci, içerisinde karşılıklı etkileşimlerin ve ilişkilerin olduğu, alıcı ve satıcı konumundaki kurumların yer aldığı bir yapıdır. Bu yapı içerisinde devlet, yapmış olduğu kamu alımları ve ihalelerine ilişkin düzenlemeler ile sürecin kurallarını belirlemektedir. Günümüzde ülkelerin ekonomik büyüme ve kalkınma yolunda inovasyonun ön plana çıkmasıyla devletin kamu alımlarında yenilikçi fikirlere ağırlık verdiği görülmektedir. Dolayısıyla içerisinde birçok aktörün ve etkileşimin yer aldığı kurumlar kümesi olarak nitelendirilen kamu alım süreçlerinin inovasyon özelinde yeniden tasarlanması gerekmektedir. Ülkedeki teknolojiyi geliştirecek, yeni fikirleri uygulamaya dönüştürecek, özel sektörün yenilikçi çözümler üretmesini teşvik edecek bir şekilde yenilikçi kamu 
alımlarına ilişkin hukuki altyapının, özellikle yenilikçi fikirlerle gelen firmaları ödüllendiren ihale yöntemlerinin hazırlanması, kamu alımlarında yenilikçi çözümlere öncelik verilmesi gibi formel kurumların oluşturulmasına ihtiyaç bulunmaktadır. Yine özel sektörün yenilikçi fikirlere ve rekabet güçlerini artırabilmek için inovasyona değer veren, diğer firmalar ile bu alanda işbirliği ve etkileşimin var olduğu enformel kurumların da gelişmesi gerekmektedir. $\mathrm{Bu}$ açılardan devletin yenilikçi kamu alım süreçlerinde formel kurumları oluşturması beraberinde piyasada yer alan diğer aktörler arasında enformel kurumların gelişmesine de yol açması muhtemel görünmektedir.

\section{Kaynaklar}

Acemoglu, D. (2003), "Root Causes: A Historical Approach to Assessing the Role of Institutions in Economic Development", Finance and Development, 40(2), 27-30.

Acemoglu, D. \& S. Johnson \& J. Robinson (2004), "Institutions as the Fundamental Cause of LongRun Growth", NBER Working Paper, No. 10481, 1-111.

Aghion, P. \& N. Bloom \& R. Blundell \& R. Griffith \& P. Howitt (2005), "Competition and Innovation: An Inverted-U Relationship", Quarterly Journal of Economics, 120(2), 701728.

Aktan, C.C. \& T. Vural (2006a), "Kurallar ve Kurumların Sosyolojik Temelleri Üzerine Bir İnceleme: Terminoloji ve Tipoloji”, Kurallar, Kurumlar ve Düzen: Kurallar ve Kurumlarin Sosyolojik Temelleri (1-15), Ankara: Sermaye Piyasası Kurulu, Kurumsal Araştırmalar Serisi No: 1.

Aktan, C.C. \& T. Vural (2006b), "Kurallar ve Kurumların Oluşumu. Kurallar, Kurumlar ve Düzen”, Kurallar ve Kurumların Sosyolojik Temelleri (63-77), Ankara: Sermaye Piyasası Kurulu, Kurumsal Araştırmalar Serisi No: 1.

Aktan, C.C. \& H. Çoban (2007), "Kamu Maliyesinde Güven ve Ekonomik Anayasa”, Çimento Işsveren Dergisi, 6(21), 4-11.

Almeida, H. \& H. Pinto \& C. Nogueira (2014), "Social, Human Capital and Innovation: An Exploratory Study of European Atlantic Organisations", Advances in Social Sciences Research Journal, 1(4), 87-103.

Arrow, K. (1962), "Economic Welfare and the Allocation of Resources for Invention", in: P. Stephan \& D. Audrestch (eds.), The Economics of Science and Innovation, 1(61-77) Edward Elgar, Cheltham.

Barbosa, N. \& P.F. Faria (2011), "Innovation across Europe: How important are institutional differences?", Research Policy, 40, 1157-1169.

Biber, A.E. (2010), “İktisadi Büyümede Kurumsal Faktörler ve Kurumsal Değişim”, Akademik Bakış Dergisi, 19, 1-24.

Blind, K. (2012), "The Influence of Regulations on Innovation: A Quantitative Assessment for OECD Countries", Research Policy, 41(2), 391-400.

Blundell, R. \& R. Griffith \& J.V. Reenen (1999), "Market Share, Market Value and Innovation in A Panel of British Manufacturing Firms", Review of Economic Studies, 66(3), 529-55.

Borras, S. \& C. Edquist (2013), “The Choice of Innovation Policy Instruments”, Technological Forecasting \& Social Change, 80, 1513-1522.

Boztosun, N.A. (2007), "Fikri Mülkiyet ve Küresel Rekabet”, TÜSIAD-Sabancı Üniversitesi Rekabet Forumu, REF 08/2007, 1-14. 
Buchanan, J.M. \& A. Di Pierro (1980), “Cognition, Choice, and Entrepreneurship”, Southern Economic Journal, 46(3), 693-701.

Carden, W.A. (2007), “Christian Ethics, Formal Institutions, and Economic Growth”, American Review of Political Economy, 5(1), 34-53.

Carlsson, B. \& S. Jacobsson (1997), “Diversity Creation and Technological Systems: A Technology Policy Perspective” in: C. Edquist (ed.), Systems of Innovation: Technologies, Institutions and Organizations, Pinter Publisher, London.

Coleman, J.S. (1988), "Social Capital in the Creation of Human", The American Journal of Sociology, 94, 95-120.

Commons, J.R. (1931), "Institutional Economics", American Economic Review, 21, 648-657.

Dakhli, M. \& D.D. Clercq (2004), "Human Capital, Social Capital and Innovation: A Multi-Country Study", Entrepreneurship \& Regional Development, 16(2), 107-128.

EC (2005), Public Procurement for Research and Innovation: Developing Procurement Practices Favourable to $R \& D$ and Innovation, <http://ec.europa.eu/invest-in research/pdf/download_en/edited_report_18112005_on_public_procurement_for_researc h_and_innovation.pdf>, 05.03.2016.

EC (European Commission) (1995), Green Paper on Innovation, <http://cordis.europa.eu/publication/rcn/361_en.html>, 01.03.2016.

Edquist, C. \& L. Hommen (2000), "Public Technology Procurement and Innovation Theory”, in: C. Edquist \& L. Hommen \& L.J. Tsipouri (eds.), Public Technology Procurement and Innovation, Boston/Dordrecht/London: Kluwer Academic Publishers, 5-64.

Edquist, C. (2005), "Systems of innovation: perspectives and challenges", in: J. Fagerberg, et al. (eds.), The Oxford Handbook of Innovation, Oxford University Press, 181-208.

Edquist, C. (2015), "Innovation-related Public Procurement as a Demand-oriented Innovation Policy Instrument”, Lund University, CIRCLE Working Paper, No 2015/28, 1-43.

Georghiou, L. \& J. Edler \& E. Uyarra \& J. Yeow (2014), "Policy Instrument for Public Procurement of Innovation: Choice, Design and Assessment", Technological Forecasting \& Social Change, 86, 1-12.

Gimeno, J. \& T.B. Folto \& A.C. Cooper \& C.Y. Woo (1997), "Survival of the Fittest? Human capital and the Persistence of Underperforming Firms", Administrative Science Quarterly, 42(4), 750-783.

Globerman, S. (2012), “ Public Policies to Encourage Innovation and Productivity”, True North in Canadian Public Policy, The Macdonald-Laurier Institute, September, 1-19.

Gregersen, B. \& B. Johnson (1996), "Learning Economies, Innovation Systems and European Integration”, Regional Studies, 31, 479-490.

Greif, A. (2006), Institutions and the Path to the Modern Economy: Lessons from Medieval Trade, USA. Cambrigde University Press.

Hommen, L. \& M. Rolfstam (2009), "Public Procurement and Innovation: Towards a Taxonomy", Journal of Public Procurement, 9(1), 17-56.

Hwang, H. \& W.W. Powell (2005), "Institutions and entrepreneurship", in: S.A. Alvarez \& R. Agarwal \& O. Sorenson (eds.), Handbook of entrepreneurship research: Disciplinary Perspectives, (201-232), New York: Springer.

Kapp, K.W. (1968), "In Defense of Institutional Economics”, The Swedish Journal of Economics, 70(1), 1-18. 
Kasper, W. \& M.E. Streit (1998), “Institutional Economics, Social Order and Public Policy”, Cheltenham: The Locke Institute, Edward Elgar.

Kuhlmann, S. \& E. Arnold (2001), RCN in the Norwegian Researh and Innovation System, <https://www.regjeringen.no/globalassets/upload/kd/vedlegg/forskning/rapporter/2001ren-eval/2001-rcn-evaluation-background-report-no-12.pdf?id=2248274>, 21.03.2016.

Lember, V. \& R. Kattel \& T. Kalvet (2014), "Public Procurement and Innovation: Theory and Practice", in: Public Procurement, Innovation and Policy: International Perspectives, (eds.) V. Lember \& R. Kattel \& T. Kalvet, Springer Publications, 13-35.

Li, Y. (2013), Public Procurement as a Demand-side Innovation Policy in China - An Exploratory and Evaluative Study, <https://www.escholar.manchester.ac.uk/uk-ac-man-scw:222567〉, 15.03.2016.

Lundvall, B. (1995), "Introduction”, in: B. Lundvall (ed.), National Systems of Innovation - Towards A Theory of Innovation and Interactive Learning, Biddles, London, 1-19.

Mahendra, E. \& U. Zuhdi \& R. Muyanto (2015), "Determinants of Firm Innovation in Indonesia: The Role of Institutions and Access to Finance", TMCD Working Paper, WP-64, 1-41.

Marsh, I. (2010), "Innovation and Public Policy: The Challenge of an Emerging Paradigm", AIRC Working Paper Series, WP/0710, 1-44.

National ICT Research Directors Forum (2006), Pre-Commercial Procurement of Innovation: A Missing Link in The European Innovation Cycle, $<\mathrm{ftp}$ ://ftp.cordis.europa.eu/pub/fp7/ict/docs/pcp/precommercial-procurement-ofinnovation_en.pdf $>$, 03.03.2016.

Neale, W.C. (1987), "Institutions”, Journal of Economic Issues, 21(3), 1177-1206.

Nelson, R.R. \& N. Rosenberg (1993), “Technical Innovation and National Systems”, in: R. Nelson (ed.) National Innovation Systems - A Comparative Analysis, Oxford University Press, New York, 3-21.

Nelson, R.R. (1993), “National Innovation Systems: A Comparative Analysis”, Oxford: Oxford University Press.

Nelson, R.R. \& K. Nelson (2002), “Technology, Institutions, and Innovation Systems”, Research Policy, 31, 265-272.

Nickell, S.J. (1996), “Competition and corporate performance”, Journal of Political Economy, 104(4), 724-746.

North, D.C. (2010), Kurumlar, Kurumsal Değişim ve Ekonomik Performans, Çev. Gül Çağalı Güven, Sabancı Üniversitesi Yayınları, İstanbul.

OECD (1997), National Innovation Systems, 〈http://www.oecd.org/science/inno/2101733.pdf>, 21.03.2016.

OECD (2001), “The Well-Beings of Nations, The Role of Human and Social Capital”, OECD Publications, 1-118.

OECD (2005), Oslo Manual: Guidelines for Collecting and Interpreting Innovation Data, $3^{\text {rd }}$ ed. Luxembourg: OECD Publishing.

OECD (2011), “Demand-side Innovation Policies”, OECD Publishing, 1-190.

Putnam R.D. \& R. Leonardi \& R. Nanetti (1993), Making Democracy Work: Civic Traditions in Modern Italy, Princeton: Princeton University Press.

Rauf, M. (2009), "Innovations and Informal Institutions: An Institutionalist Approach to the Role of Social Capital for Innovation", Journal of Academic Research in Economics, 1, 25-34. 
Rolfstam, M. (2012a), “Understanding Public Procurement of Innovation: Definitions, Innovation Types and Interaction Modes", Social Science Research Network, 1-16.

Rolfstam, M. (2012b), "An Institutional Approach to Research on Public Procurement of Innovation", The European Journal of Social Science Research, 25(3), 303-321.

Romer, P.M. (1986), “Increasing Returns and Long-Run Growth”, The Journal of Political Economy, 94(5), 1002-1037.

Romer, P.M. (1990), "Endogenous Technological Change”, The Journal of Political Economy, 98(5), 71-102.

Schumpeter, J.A. (1942), Capitalism, Socialism and Democracy, Harper and Row, New York.

Schumpeter, J.A. (1939), Business Cycles: A Theoretical, Historical, and Statistical Analysis of The Capitalist Process, New York And London: Mcgraw-Hill.

Silve, F. \& A. Plekhanov (2015), "Institutions, Innovation and Growth: Cross-country Evidence", EBRD Working Paper/177, 1-30.

Solow, R.M. (1956), “A Contribution to the Theory of Economic Growth”, The Quarterly Journal of Economics, 70(1), 65-94.

Sowell, T. (1967), “The Evolutionary Economics of Thorstein Veblen”, Oxford Economic Papers, New Series, 19(2), 177-198.

Srholec, M. (2011), “A Multilevel Analysis of Innovation in Developing Countries”, Industrial and Corporate Change, 20(6), 1539-1569.

Tebaldi, E. \& B. Elmslie (2013), "Does Institutional Quality Impact Innovation? Evidence from Cross-Country Patent Grant Data", Applied Economics, 45(7), 887-900.

Turanlı, R. \& E. Sarıdoğan (2010), Bilim-Teknoloji-İnovasyon Temelli Ekonomi ve Toplum, İTO Yayın1, Say1 2010/13.

Veblen, T. (1909), “The Limitations of Marginal Utility”, Journal of Political Economy, 17(9), 620636.

Williams, L. Heidi (2010), "Intellectual Property Rights and Innovation: Evidence from the Human Genome", NBER Working Paper, No. 16213, 1-9. 
Bakırtaş, D. \& A. Aysu (2017), "Kurumsal Yaklaşım Perspektifinden İnovasyon ve Yenilikçi Kamu Alımları”, Sosyoekonomi, Vol. 25(31), 127-147. 